Brit. J. vener. Dis. (1965), 41, 90.

TRICHOMONIASIS*

\title{
STUDY OF THE DISEASE AND ITS TREATMENT
}

BY

\author{
ANTHONY R. WISDOM† AND ERIC M. C. DUNLOP \\ Whitechapel Clinic, The London Hospital, London
}

\section{THE DISEASE AND ITS TREATMENT IN WOMEN}

Trichomonas vaginalis is commonly found in the genito-urinary tract. One or more tests for trichomonal infestation were carried out on 1,424 women attending the Whitechapel Clinic of The London Hospital during the year beginning July 1 , 1960 , and $449(31 \cdot 5$ per cent.) of the patients were found to be harbouring the parasite. Of this number, 391 had a single episode of infestation in the year under review, 52 had two episodes, and 6 had three. An attack of trichomoniasis was recorded as a separate episode if a period of three months or more had elapsed since the treatment of a previous attack. Thus 513 episodes were recorded, amounting to 38 per cent. of the total of 1,355 cases of sexually transmitted disease diagnosed during the year under review. Search for the parasite is therefore essential in the cases of all women investigated for such disease.

\section{Patients}

Findings with regard to age, race, civil state, occupation, and pregnancy in the cases of the 449 female patients suffering from trichomoniasis are recorded in Table I.

Past History.- No data were available in the cases of 19 patients. Of the remaining 430 patients, 159 ( 38 per cent.) gave a history of a total of 543 episodes of sexually transmitted disease (excluding treponemal infection); 108 of these patients had previously been infested with $T$. vaginalis on one or more occasions, 98 had had one or more attacks of gonorrhoea, and 49 had suffered from salpingitis. These attacks had occurred from one month to more than ten years prior to the period under review; 271 patients (62 per cent.) gave no history of any such previous attack.

* Received for publication September 14, 1964.

† Now at Oldchurch Hospital, Romford, Essex.
Reason for Attendance.-The reasons for attendance of the patients who suffered 513 attacks of trichomonal infestation are shown in Table II. In no less than 46 per cent. of cases the patients came of their own accord, in 24 per cent. they came as contacts, in $20 \cdot 5$ per cent. they were referred by other doctors, and in 9.5 per cent. they came for follow-up examinations after a previous attack of trichomoniasis or of another sexually transmitted disease.

Associated Sexually Transmitted Infections.-In 283 of the 513 cases ( 55 per cent.) trichomoniasis was the only sexually transmitted infection present. In 230 cases (45 per cent.) trichomoniasis occurred in association with one or more of the other sexually transmitted infections (Table III). Gonorrhoea was diagnosed in 155 (30 per cent.) of the 513 cases, and this was complicated by salpingitis in 17 (11 per cent. of the 155). Moniliasis was present in 29 (6 per cent.) of the 513 cases, genital warts in 22 (4 per cent.) nonspecific salpingitis in 17 ( 3 per cent.), and nonspecific bartholinitis was found in 4 cases $(0.8$ per cent.). Untreated treponemal disease was found in 15 ( 3 per cent.) of the 513 cases.

In 38 of the 449 patients $(8 \cdot 5$ per cent.) a diagnosis of treponemal disease was made. In 15 (3 per cent.) the disease was hitherto untreated; in 23 ( 5 per cent.) it had been previously treated. Twenty-two of the cases of treponemal disease occurred in coloured patients and may have been due to either syphilis or yaws; the remaining 16 had syphilis.

Symptoms and Signs.-The symptoms in the 513 cases of trichomoniasis are recorded in Table IV and the signs in Tables V and VI. Each of these tables is in two parts: in part $A$ the findings in the whole group have been recorded; in part B all cases of gonorrhoea, moniliasis, genital warts, non-specific 
TABLE I

AGE, NATIONALITY, CIVIL STATE, OCCUPATION, AND PREGNANCY OF 449 FEMALE PATIENTS

\begin{tabular}{|c|c|c|c|c|c|c|c|c|c|}
\hline$\underset{(y r s)}{\text { Age Group }}$ & $\begin{array}{l}\text { No. of } \\
\text { Patients }\end{array}$ & Nationality & $\begin{array}{l}\text { No. of } \\
\text { Patients }\end{array}$ & $\begin{array}{l}\text { Civil } \\
\text { State }\end{array}$ & $\begin{array}{l}\text { No. of } \\
\text { Patients }\end{array}$ & Occupation & $\begin{array}{l}\text { No. of } \\
\text { Patients }\end{array}$ & Pregnancy & $\begin{array}{l}\text { No. of } \\
\text { Patients }\end{array}$ \\
\hline $\begin{array}{ll}10-19 & \ldots \\
20-29 & \ldots \\
30-39 & \ldots \\
40-49 & \ldots \\
50 & \text { and over }\end{array}$ & $\begin{array}{r}100 \\
222 \\
92 \\
32 \\
3\end{array}$ & $\begin{array}{l}\text { British } \\
\text { Other White } \\
\text { Caribbean } \\
\text { Other Coloured } \\
\text { No data }\end{array}$ & $\begin{array}{r}338 \\
25 \\
82 \\
2 \\
2\end{array}$ & $\begin{array}{l}\text { Single . . } \\
\text { Married.. } \\
\text { Widowed } \\
\text { Separated } \\
\text { Divorced } \\
\text { No data. . }\end{array}$ & $\begin{array}{r}227 \\
176 \\
3 \\
34 \\
6 \\
3\end{array}$ & $\begin{array}{l}\text { Housewife } . . \\
\text { Factory worker } \\
\text { Clerical worker } \\
\text { Miscellaneous. . } \\
\text { Prostitute } \\
\text { Unemployed } \\
\text { No data }\end{array}$ & $\begin{array}{r}113 \\
120 \\
38 \\
108 \\
24 \\
43 \\
3\end{array}$ & $\begin{array}{l}\text { Pregnant } \\
\text { Not pregnant ... } \\
\text { Default before } \\
\quad \text { assessment ... }\end{array}$ & $\begin{array}{r}69 \\
365 \\
15\end{array}$ \\
\hline Total & 449 & Total & 449 & Total & 449 & Total & 449 & Total & 449 \\
\hline
\end{tabular}

TABLE II

REASON FOR ATTENDANCE OF 449 WOMEN WITH 513 ATTACKS OF TRICHOMONIASIS

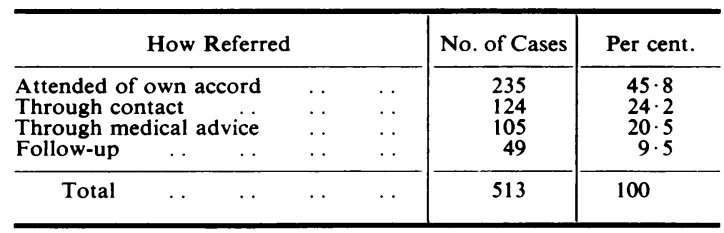

salpingitis, and bartholinitis have been excluded.

Excluding the cases in which the necessary data were not recorded, 68 per cent. of the whole group complained of vaginal discharge compared with 72 per cent. of the group with trichomoniasis alone; vulval soreness occurred in 13.5 per cent. compared with 18 per cent.; vulval irritation in 18 per cent. compared with 21 per cent.; pain on passing urine in 17 per cent. compared with 16 per cent.; increased frequency of micturition in 9 per cent. compared with 8 per cent.; awareness of unpleasant odour in 7 per cent. compared with $10 \cdot 5$ per cent. There was abdominal pain in 66 (13 per cent.) of 497 cases in group $\mathrm{A}$. This included the 34 cases of salpingitis, both gonococcal and non-specific.

Not only was vaginal discharge the commonest symptom but it was also the commonest sign; it was present in 81 per cent. of 442 unselected cases of trichomoniasis (Table $\mathrm{VA}_{\mathrm{A}}$ ) and in 93 per cent. of
TABLE III

ASSOCIATED SEXUALLY TRANSMITTED INFECTIONS IN 230 OF 513 CASES

\begin{tabular}{|c|c|c|c|}
\hline Diagnosis & & No. of & Per cent. \\
\hline 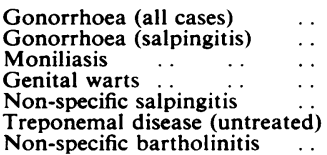 & $\begin{array}{l}\ldots \\
\ldots \\
\ldots \\
\ldots \\
\ldots \\
\ldots \\
\ldots\end{array}$ & $\begin{array}{r}155 \\
17 \\
29 \\
22 \\
17 \\
15 \\
4\end{array}$ & $\begin{array}{r}30 \cdot 2 \\
3 \cdot 3 \\
5 \cdot 7 \\
4 \cdot 3 \\
3 \cdot 3 \\
2 \cdot 9 \\
0 \cdot 8\end{array}$ \\
\hline
\end{tabular}

230 cases of trichomoniasis alone (Table VB). There was perivulvitis in 9 per cent. compared with 11 per cent.; vulvitis in 38 per cent. compared with 43 per cent.; urethritis in 25 per cent. compared with 26 per cent.; and vaginitis in 81 per cent. compared with 82 per cent.

The type of discharge, when present, is recorded in Table VI.

The vaginal discharge was the classic "frothy" type in only 31 per cent. of cases of discharge in this whole group and in 29 per cent. of cases in those with trichomoniasis alone (Table VI). The character of the discharge was much the same in the two groups.

There were great variations in the clinical manifestations of trichomoniasis. In 48 cases ( 9 per cent. of 513) there were no symptoms and in 24 of these ( 5 per cent. of 513) there were no abnormal findings. A number of patients without symptoms attended as

TABLE IV

TRICHOMONIASIS: NATURE, SEVERITY, AND FREQUENCY OF SYMPTOMS

\begin{tabular}{|c|c|c|c|c|c|c|c|}
\hline & Severity & Discharge & Soreness & Irritation & $\begin{array}{c}\text { Pain on } \\
\text { Passing Urine }\end{array}$ & $\begin{array}{l}\text { Increased } \\
\text { Frequency }\end{array}$ & Odour \\
\hline $\begin{array}{l}\text { A. } \\
\text { Ail Cases }\end{array}$ & $\begin{array}{ll}\text { Marked } & \ldots \\
\text { Slight } & \ldots \\
\text { None } & \text { Not recorded }\end{array}$ & $\left.\begin{array}{r}93 \\
244 \\
161 \\
15\end{array}\right\} 67 \cdot 7 \%$ & $\left.\begin{array}{r}21 \\
46 \\
430 \\
16\end{array}\right\} 13 \cdot 5 \%$ & $\left.\begin{array}{r}21 \\
68 \\
408 \\
16\end{array}\right\} 17 \cdot 9 \%$ & 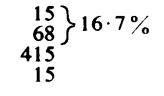 & $\left.\begin{array}{r}16 \\
29 \\
452 \\
16\end{array}\right\} 9 \cdot 1 \%$ & $\left.\begin{array}{l}11 \\
24 \\
461 \\
17\end{array}\right\} 7 \cdot 1 \%$ \\
\hline \multicolumn{2}{|l|}{ Total } & 513 & 513 & 513 & 513 & 513 & 513 \\
\hline $\begin{array}{l}\text { B. } \\
\text { Tricho- } \\
\text { moniasis } \\
\text { Alone }\end{array}$ & $\begin{array}{ll}\text { Marked } & \ldots \\
\text { Slight } & \ldots \\
\text { None } & \\
\text { Not recorded }\end{array}$ & $\left.\begin{array}{c}61 \\
137 \\
78 \\
7\end{array}\right\} 71 \cdot 7 \%$ & $\left.\begin{array}{r}16 \\
34 \\
225 \\
8\end{array}\right\} 18 \cdot 2 \%$ & $\left.\begin{array}{r}15 \\
\begin{array}{r}15 \\
217 \\
8\end{array}\end{array}\right\} 21 \cdot 1 \%$ & $\begin{array}{r}\begin{array}{r}85 \\
233 \\
7\end{array} \\
\}\end{array} 15 \cdot 6 \%$ & $\left.\begin{array}{r}8 \\
15 \\
252 \\
8\end{array}\right\} 8 \cdot 4 \%$ & 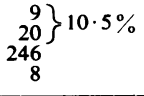 \\
\hline \multicolumn{2}{|l|}{ Total } & 283 & 283 & 283 & 283 & 283 & 283 \\
\hline
\end{tabular}


TABLE V

TRICHOMONIASIS: NATURE, SEVERITY, AND FREQUENCY OF SIGNS

\begin{tabular}{|c|c|c|c|c|c|c|c|c|}
\hline & Severity & Perivulvitis & Vulvitis & Urethritis & Vaginitis & \multicolumn{3}{|c|}{ Discharge } \\
\hline Ail Cases & $\begin{array}{ll}\text { Marked } & \ldots \\
\text { Slight } & \ldots \\
\text { None } & \text { Not recorded }\end{array}$ & $\left.\begin{array}{r}25 \\
20 \\
460 \\
8\end{array}\right\} 9 \%$ & $\left.\begin{array}{r}49 \\
141 \\
310 \\
13\end{array}\right\} 38 \%$ & $\left.\begin{array}{r}13 \\
110 \\
371 \\
19\end{array}\right\} 25 \%$ & $\left.\begin{array}{r}112 \\
294 \\
95 \\
12\end{array}\right\} 81 \%$ & $\begin{array}{l}\text { Present } \quad \ldots \\
\text { Absent } \quad \text {. } \\
\text { Not recorded }\end{array}$ & $\begin{array}{l}\cdots \\
\cdots \\
\cdots\end{array}$ & $\begin{array}{l}360(81 \cdot 4 \%) \\
82 \\
71\end{array}$ \\
\hline Total & $\ldots$ & 513 & 513 & 513 & 513 & Total & $\ldots$ & 513 \\
\hline $\begin{array}{l}\text { B. } \\
\text { Tricho- } \\
\text { moniasis } \\
\text { Alone }\end{array}$ & $\begin{array}{ll}\text { Marked } & \ldots \\
\text { Slight } & \ldots \\
\text { None } & \text { Not recorded }\end{array}$ & $\left.\begin{array}{r}17 \\
13 \\
249 \\
4\end{array}\right\} 11 \%$ & $\left.\begin{array}{c}35 \\
85 \\
158 \\
5\end{array}\right\} 43 \%$ & $\left.\begin{array}{r}8 \\
62 \\
204 \\
9\end{array}\right\} 26 \%$ & $\left.\begin{array}{r}76 \\
153 \\
50 \\
4\end{array}\right\} 82 \%$ & $\begin{array}{l}\text { Present } \quad \ldots \\
\text { Absent } \quad . \\
\text { Not recorded }\end{array}$ & $\begin{array}{l}\cdots \\
\cdots \\
\cdots\end{array}$ & $\begin{array}{l}214(93 \%) \\
16 \\
53\end{array}$ \\
\hline Total & $\ldots$ & 283 & 283 & 283 & 283 & Total & $\ldots$ & 283 \\
\hline
\end{tabular}

contacts of men suffering from gonorrhoea, and those found to have both diseases were excluded from the group with trichomoniasis alone. This accounts for some of the differences between that group and the unselected group.

TABLE VI

TYPE OF DISCHARGE

\begin{tabular}{|c|c|c|c|c|c|}
\hline \multirow{2}{*}{\multicolumn{2}{|c|}{ Discharge }} & \multicolumn{2}{|c|}{$\stackrel{\text { A. }}{\text { All Cases }}$} & \multicolumn{2}{|c|}{\begin{tabular}{|c} 
B. \\
Trichomoniasis Alone
\end{tabular}} \\
\hline & & No. & Per cent. & No. & Per cent. \\
\hline Thin & $\begin{array}{l}\text { Frothy } \\
\text { Scanty } \\
\text { Profuse }\end{array}$ & $\begin{array}{r}111 \\
42 \\
17\end{array}$ & $\begin{array}{r}31 \\
11 \\
5\end{array}$ & $\begin{array}{l}61 \\
20 \\
10\end{array}$ & $\begin{array}{r}29 \\
9 \\
5\end{array}$ \\
\hline Thick & $\begin{array}{l}\text { Muco- } \\
\text { purulent } \\
\text { Scanty } \\
\text { Profuse }\end{array}$ & $\begin{array}{l}46 \\
62 \\
82\end{array}$ & $\begin{array}{l}13 \\
17 \\
23\end{array}$ & $\begin{array}{l}28 \\
41 \\
54\end{array}$ & $\begin{array}{l}13 \\
19 \\
25\end{array}$ \\
\hline Total & .. & 360 & 100 & 214 & 100 \\
\hline
\end{tabular}

\section{Treatment}

In 444 cases treatment with metronidazole ("Flagyl", May \& Baker) was given in a dosage of $200 \mathrm{mg}$. by mouth 3 times daily after meals for 7 days, and the results of treatment were assessed.

Follow-up.-All patients were asked to attend at the end of treatment, at weekly intervals for two further weeks, and then after each menstrual period, or at intervals of four weeks, until they had been observed and tested for 90 days. At each attendance a wet vaginal smear was examined microscopically, without delay, for the presence of $T$. vaginalis and, in addition, fresh specimens of urine and of vaginal secretion were cultured in Feinberg-Whittington medium at the end of treatment and 90 days or more from the start of treatment.

Patients were advised to abstain from sexual intercourse for four weeks after treatment had been completed and were questioned about sexual activity at each follow-up visit. When possible the male consort was examined and if necessary treated, preferably while his partner was still under treatment.
In 289 cases treatment was completed as ordered and results could be assessed. In 32 cases the patients took none or only some of the metronidazole. In 123 cases the patients did not return for assessment.

Toxic Effects of Treatment.-In 268 (93 per cent.) of the 289 cases treatment was completed without complication. In 21 cases ( 7 per cent.) there were mild toxic effects but none was severe enough to curtail treatment. In 14 of these there was some disturbance of the alimentary tract, consisting for the most part of nausea, bad taste in the mouth, loss of appetite, vomiting, soreness of the mouth, and furring of the tongue. In 4 cases there were headache and dizziness. In 3 there were transient skin eruptions.

Results of Treatment.-Of the 289 cases in which treatment was completed, 284 were assessed at the end of treatment and trichomonads could not be found in 278 (98 per cent.) (Tables VII and VIII); symptoms due to trichomoniasis had been completely or partially relieved in 96.5 per cent. and signs of infestation had been completely or partially relieved in 98 per cent.

The duration of follow-up and the results are recorded in Table VIII. Observation for 90 days was completed and the patients remained free from infestation with $T$. vaginalis in 104 cases $(72 \cdot 2$ per cent.). Relapse or re-infestation during this period occurred in 40 cases ( 28 per cent.); in 3 of these relapse appeared likely, but in most the distinction between relapse and re-infestation could not be made with any certainty. In 145 cases patients defaulted before observation for 90 days had been completed, all being apparently cured at the time of default. In 123 cases the patients defaulted without any followup and in 32 cases the patients failed to take the treatment as prescribed.

\section{Summary}

Infestation with $T$. vaginalis in 513 cases, involving 449 patients, was found among 1,355 cases of sexually transmitted infection in women attending 
the Whitechapel Clinic of The London Hospital in the year beginning July 1, 1960, an incidence of 38 per cent. The patients and the clinical manifestations are described. Treatment with $200 \mathrm{mg}$. of metronida- zole by mouth 3 times a day for 7 days gave an immediate success rate of 98 per cent. in 284 cases and a success rate after three months of 72 per cent. in 144 cases.

TABLE VII

IMMEDIATE RESULTS OF TREATMENT

\begin{tabular}{|c|c|c|c|c|c|c|c|c|c|c|}
\hline \multicolumn{2}{|c|}{ Smears, Cultures } & \multirow{2}{*}{$\begin{array}{c}\text { No. of Cases } \\
278(97.9 \%)\end{array}$} & \multicolumn{3}{|c|}{ Symptoms } & \multirow{2}{*}{ 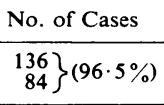 } & \multicolumn{3}{|c|}{ Signs } & \multirow{2}{*}{ 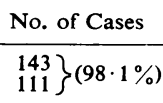 } \\
\hline$T$. vaginalis absent & $\ldots$ & & $\begin{array}{l}\text { Relieved . } \\
\text { Improved }\end{array}$ & $\begin{array}{l}\cdots \\
\cdots\end{array}$ & $\begin{array}{l}\cdots \\
\cdots\end{array}$ & & $\begin{array}{l}\text { Relieved . . } \\
\text { Improved }\end{array}$ & $\begin{array}{l}\cdots \\
\cdots\end{array}$ & $\begin{array}{l}\cdots \\
\cdots\end{array}$ & \\
\hline$T$. vaginalis present & $\cdots$ & $6(2 \cdot 1 \%)$ & $\begin{array}{l}\text { Unchanged } \\
\text { Not recorded }\end{array}$ & $\begin{array}{l}\cdots \\
\cdots\end{array}$ & $\begin{array}{l}\cdots \\
\cdots\end{array}$ & $20(3 \cdot 5 \%)$ & $\begin{array}{l}\text { Unchanged } \\
\text { Not recorded }\end{array}$ & $\begin{array}{l}\cdots \\
\cdots\end{array}$ & $\begin{array}{l}\cdots \\
\cdots\end{array}$ & $\begin{array}{l}5 \\
8\end{array}(1.9 \%)$ \\
\hline Not recorded & $\cdots$ & 5 & None initially & $\cdots$ & $\cdots$ & 41 & None initially & · & $\cdots$ & 22 \\
\hline Total & . & 289 & Total & . & . & 289 & Total & . & $\cdots$ & 289 \\
\hline
\end{tabular}

TABLE VIII

OUTCOME WITH CUMULATIVE RELAPSE-RE-INFECTION RATE

\begin{tabular}{|c|c|c|c|c|c|c|c|c|c|c|c|}
\hline Follow-up in days* & . & $\cdots$ & . & . & 7 & $8-14$ & $15-21$ & $22-30$ & $31-60$ & $61-89$ & 90 or more \\
\hline No. examined & . & $\cdots$ & $\cdots$ & $\cdots$ & 289 & 275 & 236 & 216 & 183 & 159 & 144 \\
\hline $\begin{array}{c}\text { T. vaginalis not found } \\
\text { No. . . } \\
\text { Per cent. }\end{array}$ & $\begin{array}{l}\ldots \\
\cdots\end{array}$ & $\begin{array}{l}\cdots \\
\cdots\end{array}$ & $\begin{array}{l}\cdots \\
\cdots\end{array}$ & $\begin{array}{l}\cdots \\
\cdots\end{array}$ & $\begin{array}{c}278 \\
97 \cdot 9 \\
(5 \text { no data) }\end{array}$ & $\begin{array}{l}260 \\
94 \cdot 5\end{array}$ & $\begin{array}{r}215 \\
91 \cdot 1\end{array}$ & $\stackrel{189}{87 \cdot 5}$ & $\begin{array}{l}149 \\
81 \cdot 4\end{array}$ & $\begin{array}{l}119 \\
74 \cdot 8\end{array}$ & $\begin{array}{r}104 \\
72 \cdot 2\end{array}$ \\
\hline $\begin{array}{c}\text { T. vaginalis found } \\
\text { No. . } \\
\text { Per cent. }\end{array}$ & $\begin{array}{l}\ldots \\
\cdots\end{array}$ & $\begin{array}{l}\cdots \\
\cdots\end{array}$ & $\begin{array}{l}\cdots \\
\cdots\end{array}$ & $\begin{array}{l}\ldots \\
\ldots\end{array}$ & $\begin{array}{l}6 \\
2 \cdot 1\end{array}$ & $\begin{array}{l}15 \\
5 \cdot 5\end{array}$ & $\begin{array}{l}21 \\
8 \cdot 9\end{array}$ & $\begin{array}{l}27 \\
12 \cdot 5\end{array}$ & $\begin{array}{l}34 \\
18 \cdot 6\end{array}$ & $\begin{array}{l}40 \\
25 \cdot 2\end{array}$ & $\begin{array}{l}40 \\
27 \cdot 8\end{array}$ \\
\hline Late default & $\cdots$ & $\cdots$ & $\cdots$ & $\cdots$ & - & 14 & 53 & 73 & 106 & 130 & 145 \\
\hline Immediate default. . & $\cdots$ & $\cdots$ & $\cdots$ & $\cdots$ & 123 & 123 & 123 & 123 & 123 & 123 & 123 \\
\hline Insufficient treatment & $\cdots$ & $\cdots$ & $\cdots$ & $\cdots$ & 32 & 32 & 32 & 32 & 32 & 32 & 32 \\
\hline Total . . & $\cdots$ & $\cdots$ & $\cdots$ & $\cdots$ & 444 & 444 & 444 & 444 & 444 & 444 & 444 \\
\hline
\end{tabular}

\section{THE DISEASE AND ITS TREATMENT IN MEN}

The protozoon Trichomonas vaginalis is the most commonly recognized causative agent of nongonococcal urethritis. In the year beginning July 1, 1960, 1,646 cases of non-gonococcal urethritis were diagnosed at the Whitechapel Clinic of The London Hospital. In each of these a search for $T$. vaginalis was made, at the least, by a microscopic examination of a wet smear of urethral material. In 92 of these cases ( $5 \cdot 6$ per cent.) $T$. vaginalis was found. The 92 episodes affected 86 men. In the cases of 82 patients the parasite was found on one occasion, in 3 on two occasions and, in that of one patient, on four separate occasions.

\section{Patients}

Table IX gives details of the age, civil state, nationality, and occupation of the 86 patients. None was known to be homosexual.
Past History.-No data were available on 7 patients; 46 (58 per cent.) gave a history of a total of 198 previous episodes of sexually transmitted disease, excluding treponemal infection, these episodes having occurred from one month to more than twenty years prior to the period under review. The episodes included 88 attacks of gonococcal urethritis and 81 attacks of non-gonococcal urethritis, and 14 patients (18 per cent.) had each had one previous attack of trichomonal infestation; 33 (42 per cent.) gave no history of previous sexually transmitted disease.

Attendance.-How the 86 patients came to attend the clinic with 92 attacks of trichomoniasis is shown in Table X.

Associated Sexually Transmitted Disease.-In 72 of the 92 cases ( 78 per cent.) trichomoniasis was the only sexually transmitted disease (excluding possible non-specific urethritis) present at the time of 
TABLE IX

AGE, CIVIL STATE, NATIONALITY, AND OCCUPATION OF 86 MALE PATIENTS

\begin{tabular}{|c|c|c|c|c|c|c|c|c|c|c|c|c|c|}
\hline \multicolumn{3}{|c|}{ Age (yrs) } & \multirow{2}{*}{$\begin{array}{r}\text { No. } \\
1 \\
28 \\
43 \\
9 \\
5\end{array}$} & \multicolumn{3}{|c|}{ Civil State } & \multirow{2}{*}{$\begin{array}{r}\text { No. } \\
37 \\
43 \\
6\end{array}$} & \multicolumn{2}{|c|}{ Nationality } & \multirow{2}{*}{$\begin{array}{r}\text { No. } \\
18 \\
11 \\
41 \\
13 \\
3\end{array}$} & \multicolumn{2}{|c|}{ Occupation } & \multirow[b]{2}{*}{$\begin{array}{r}\text { No. } \\
44 \\
12 \\
1 \\
1 \\
23 \\
4 \\
1\end{array}$} \\
\hline $\begin{array}{l}10-19 \\
20-29 \\
30-39 \\
40-49 \\
50+\end{array}$ & $\begin{array}{l}\cdots \\
\cdots \\
\cdots \\
\cdots\end{array}$ & $\begin{array}{l}\cdots \\
\cdots \\
\cdots \\
\cdots\end{array}$ & & $\begin{array}{l}\text { Single . } \\
\text { Married } \\
\text { Separated }\end{array}$ & $\begin{array}{l}\cdots \\
\cdots \\
\cdots\end{array}$ & $\begin{array}{l}\cdots \\
\cdots \\
\cdots\end{array}$ & & $\begin{array}{l}\text { British . } \\
\text { Other White } \\
\text { Caribbean } \\
\text { Other Negro } \\
\text { Asian .. }\end{array}$ & $\begin{array}{l}\cdots \\
\cdots \\
\cdots \\
\cdots\end{array}$ & & $\begin{array}{l}\text { Manual .. } \\
\text { Factory worker } \\
\text { Clerical worker } \\
\text { Transient .. } \\
\text { Miscellaneous } \\
\text { Nil . . } \\
\text { Not recorded .. }\end{array}$ & $\begin{array}{l}\cdots \\
\cdots \\
\cdots \\
\cdots \\
\cdots \\
\cdots\end{array}$ & \\
\hline \multicolumn{3}{|c|}{ Total } & 86 & & & & 86 & & & 86 & & & 86 \\
\hline
\end{tabular}

TABLE $X$

ATTENDANCE OF 86 MEN WITH 92 ATTACKS OF TRICHOMONIASIS

\begin{tabular}{|c|c|c|c|c|c|c|c|}
\hline \multicolumn{7}{|c|}{ How Referred } & \multirow{2}{*}{$\begin{array}{c}\text { No. } \\
50 \\
14 \\
13 \\
12 \\
3\end{array}$} \\
\hline $\begin{array}{l}\text { Attended of own } \\
\text { Through medical } \\
\text { Through contact } \\
\text { Follow-up .. } \\
\text { No data .. }\end{array}$ & $\begin{array}{l}\text { accord } \\
\text { advice } \\
\ldots \\
\ldots \\
\ldots\end{array}$ & $\begin{array}{l}\cdots \\
\cdots \\
\cdots \\
\cdots\end{array}$ & $\begin{array}{l}\cdots \\
\cdots \\
\cdots \\
\cdots\end{array}$ & $\begin{array}{l}\cdots \\
\cdots \\
\cdots \\
\cdots\end{array}$ & $\begin{array}{l}\cdots \\
\cdots \\
\cdots \\
\cdots\end{array}$ & $\begin{array}{l}\cdots \\
\cdots \\
\cdots \\
\cdots\end{array}$ & \\
\hline Total .. & $\ldots$ & $\ldots$ & $\ldots$ & $\ldots$ & $\ldots$ & $\ldots$ & 92 \\
\hline
\end{tabular}

examination. In 20 cases ( 22 per cent.) trichomoniasis occurred in association with other sexually transmitted infection. In 8 cases there was associated gonococcal urethritis, in 3 there were genital warts, and in 9 untreated treponemal disease was found. A further 10 patients had previously received treatment for treponemal disease so, in all, a diagnosis of treponemal disease was made in 19 ( 22 per cent.) of 86 patients.

In 20 cases systemic treatment for non-specific urethritis was required during the period of observation.

Symptoms and Signs.-The symptoms and signs in the 92 cases studied are shown in Tables XI-XIV.

There was complaint of urethral discharge in 59 cases (64 per cent.); in 54 cases the discharge was slight, in 5 it was marked. There was urethral irritation on passing urine in 48 cases ( 52 per cent.); in 41 the irritation was slight, in 7 it was marked. Urethral pain on passing urine was noted in 22 cases (24 per cent.); in 17 this was slight, and in 5 it was marked. In 5 cases ( 5 per cent.) there was slight

TABLE XI

SYMPTOMS

\begin{tabular}{ll|c|c|c|c}
\hline & \multicolumn{3}{|c|}{ Severity } & & \multirow{2}{*}{ Total } \\
\cline { 2 - 3 } \cline { 5 - 5 } & Marked & Slight & Nil & \\
\hline Urethral discharge &. & 5 & 54 & 33 & 92 \\
Irritation on passing urine & 7 & 41 & 44 & 92 \\
Pain on passing urine &. & 5 & 17 & 70 & 92 \\
Increased frequency & $\ldots$ & - & 5 & 87 & 92 \\
Lower abdominal pain & $\ldots$ & - & 4 & 88 & 92 \\
Penile discomfort .. &. & - & 3 & 89 & 92 \\
\hline
\end{tabular}

increase in the frequency of micturition. In 4 cases (4 per cent.) there was lower abdominal pain, probably due to cystitis. In 3 cases ( 3 per cent.) there was discomfort of the prepuce or of the glans penis and prepuce. There were no symptoms of any kind in 17 cases (18 per cent.).

Urethritis, as shown by the presence of an excess of polymorphonuclear leucocytes in scrapings from the urethral mucous membrane, was present in all cases including the six in which $T$. vaginalis was found in the prostato-vesicular secretion and not in the urethra. There was evidence of genito-urinary infection in the two-glass test in 77 of 84 cases (92 per cent.); in 68 cases the changes were slight, in 9 they were marked. Urethral discharge was present in 67 of 88 cases ( 76 per cent.); in 47 it was slight, in 20 it was marked. Meatitis was present in 24 of 91 cases ( 26 per cent.). There was trichomonal balanoposthitis in 4 of 91 cases ( 4 per cent.) and cystitis in 4 of 84 cases ( 5 per cent.).

The urethral discharge (Table XIII) was mucoid in 24 of the 67 cases in which discharge was present (36 per cent.), mucopurulent in 23 (34 per cent.), and purulent in 20 ( 30 per cent.).

In 7 of 84 cases ( 8 per cent.) the urine in the first and second glasses was clear. In 43 cases (51 per cent.) there were shreds in the first specimen, in 30 ( 36 per cent.) there was a haze in the first specimen, and in 4 (5 per cent.) the urine in both glasses was hazy (Table XIV).

Some additional clinical details relating to the 86 patients are shown in Table XV.

Using the methods and criteria outlined by Oates (1958), evidence of non-specific prostato-vesiculitis

\begin{tabular}{l|rr|r|r|r|r}
\multicolumn{9}{c}{ TABLE XII } \\
SIGNS \\
\hline
\end{tabular}


TABLE XIII

TYPE OF URETHRAL DISCHARGE

\begin{tabular}{|c|c|c|c|c|c|c|}
\hline \multicolumn{6}{|c|}{ Type } & No. of Cases \\
\hline $\begin{array}{l}\text { Mucoid } \\
\text { Muco-purulent } \\
\text { Purulent } \quad . . \\
\text { Nil . } \\
\text { Not recorded . }\end{array}$ & $\begin{array}{l}\cdots \\
\cdots \\
\cdots \\
\cdots\end{array}$ & $\begin{array}{l}\cdots \\
\cdots \\
\cdots \\
\therefore\end{array}$ & $\begin{array}{l}\cdots \\
\cdots \\
\cdots \\
\cdots\end{array}$ & $\begin{array}{l}\ldots \\
\cdots \\
\cdots \\
\cdots\end{array}$ & $\begin{array}{l}\cdots \\
\cdots \\
\cdots \\
\cdots\end{array}$ & $\begin{array}{r}24 \\
23 \\
20 \\
21 \\
4\end{array}$ \\
\hline Total & . & . & . & $\cdots$ & $\cdots$ & 92 \\
\hline
\end{tabular}

TABLE XV

ADDITIONAL FINDINGS IN 86 PATIENTS

\begin{tabular}{|c|c|c|c|c|c|c|}
\hline & \multicolumn{2}{|c|}{ Present } & \multicolumn{2}{|c|}{ Absent } & \multirow{2}{*}{$\begin{array}{l}\text { No } \\
\text { Data }\end{array}$} & \multirow{2}{*}{ Total } \\
\hline & No. & $\begin{array}{l}\text { Per } \\
\text { cent. }\end{array}$ & No. & $\begin{array}{l}\text { Per } \\
\text { cent. }\end{array}$ & & \\
\hline 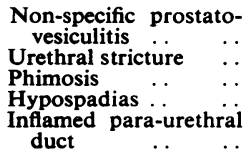 & $\begin{array}{l}8 \\
7 \\
2 \\
7 \\
3\end{array}$ & $\begin{array}{r}13 \\
12 \\
2 \\
8 \\
3\end{array}$ & $\begin{array}{l}52 \\
52 \\
84 \\
79 \\
83\end{array}$ & $\begin{array}{l}87 \\
88 \\
98 \\
92 \\
97\end{array}$ & $\begin{array}{l}26 \\
27 \\
-\end{array}$ & $\begin{array}{l}86 \\
86 \\
86 \\
86 \\
86\end{array}$ \\
\hline $\begin{array}{ll}\text { Prepuce } & \quad .\end{array}$ & 47 & 75 & 16 & 25 & 23 & 86 \\
\hline
\end{tabular}

was found in 8 of 60 patients (13 per cent.) during tests for cure (Table XV). Urethral stricture was present in 7 ( 12 per cent.) of 59 patients in whose cases urethroscopy was carried out; 2 patients had phimosis and 7 had hypospadias; thus, structural abnormalities were found in a total of 16 patients (19 per cent.).

Thirteen patients attended as contacts of women with $T$. vaginalis infestation. Eight of these patients were symptom-free and without obvious signs of infection; in these and similar cases investigation for $T$. vaginalis included tests of the early morning urethral secretion and examination of the prostatovesicular fluid.

In 6 patients $T$. vaginalis, with an excess of polymorphonuclear leucocytes, was found in the prostatovesicular fluid, but this test was not applied before treatment in those cases in which the parasite had already been found in the urethra. Following treatment, tests of the prostato-vesicular fluid gave normal results in the cases of 4 of the 6 patients; persistent prostato-vesiculitis was found in one and the remaining patient defaulted.

\section{Treatment}

In 89 cases treatment was given with metronidazole ("Flagyl", May \& Baker) in a dosage of $200 \mathrm{mg}$. 3 times a day for 7 days. Three patients defaulted without treatment.

Follow-up and Results.-All patients were asked to attend at the end of treatment, at weekly intervals for three further weeks and then at four-week intervals until the completion of observation for 90 days
TABLE XIV

TWO-GLASS TEST

\begin{tabular}{|c|c|c|}
\hline Glass 1 & Glass 2 & No. of Cases \\
\hline $\begin{array}{l}\text { Clear } \\
\text { Shreds } \\
\text { Haze } \\
\text { Haze } \\
\text { Not recorded }\end{array}$ & $\begin{array}{l}\text { Clear } \\
\text { Clear } \\
\text { Clear } \\
\text { Haze } \\
\text { Not recorded }\end{array}$ & $\begin{array}{r}7 \\
43 \\
30 \\
4 \\
8\end{array}$ \\
\hline Total .. & $\ldots$ & 92 \\
\hline
\end{tabular}

from the start of treatment. At each attendance any urethral discharge was investigated by the microscopical examination of a smear stained by Gram's method and by culture for bacteria; scrapings were also taken from the urethral mucosa and examined for trichomonads by dark-field microscopy. Cultures for trichomonads were made at the completion of treatment and after observation for 90 days. Two weeks after the end of treatment the fluid expressed by massage of the prostate and seminal vesicles was examined, and urethroscopy performed. Patients were advised to abstain from sexual intercourse for four weeks after treatment and were questioned about sexual activity at each attendance. Patients were requested to refrain from passing urine for at least three hours prior to each attendance.

In 18 cases default was immediate and no followup was possible. In 27 cases default occurred before observation for 90 days had been completed but all these patients were apparently cured at the time of default. In 38 cases observation for 90 days was completed satisfactorily, and in 6 cases relapse or reinfection occurred before that time. The prescribed treatment had been taken, without any toxic effects, by all patients who attended for follow-up. In 20 cases additional systemic treatment was required for non-specific urethritis during the period of observation. No urethral irrigation was used. The duration of the follow-up and the cumulative relapsere-infection rate recorded in Table XVI.

One patient who had four observed attacks of trichomonal urethritis was almost certainly reinfested by his consort, and his case history is given below. The cause of the re-infestation in the other cases could not be established with certainty.

\section{Case History}

A 55-year-old man attended because of symptomatic trichomonal urethritis. He stated that he was single and that he had had recent sexual intercourse with an untraceable consort. He was treated with metronidazole with initial success. Follow-up examinations, which included urethroscopy and tests of the prostato-vesicular fluid, proved satisfactory until nine weeks after treatment, when he was found to have symptomless trichomonal urethritis. He was re-treated with metronidazole and follow-up 
TABLE XVI

OUTCOME WITH CUMULATIVE RELAPSE-RE-INFECTION RATE

\begin{tabular}{|c|c|c|c|c|c|c|c|c|c|c|c|}
\hline Follow-up in Da & ys* & . & . & . & 7 & $8-14$ & $15-21$ & $22-30$ & $31-60$ & $61-89$ & 90 or more \\
\hline No. examined & $\cdots$ & $\cdots$ & $\cdots$ & $\cdots$ & 71 & 69 & 66 & 60 & 55 & 50 & 44 \\
\hline $\begin{array}{c}T \text {. vaginalis not } \mathrm{f} \\
\text { No. } \\
\text { Per cent. }\end{array}$ & $\begin{array}{l}\text { oun } \\
\cdots \\
\cdots\end{array}$ & $\begin{array}{l}\cdots \\
\cdots\end{array}$ & $\begin{array}{l}\ldots \\
\cdots\end{array}$ & $\begin{array}{l}\cdots \\
\cdots\end{array}$ & $\begin{array}{r}71 \\
100\end{array}$ & $\begin{array}{r}69 \\
100\end{array}$ & $\begin{array}{l}65 \\
98 \cdot 5\end{array}$ & $\begin{array}{l}57 \\
95\end{array}$ & $\begin{array}{l}51 \\
93\end{array}$ & $\begin{array}{l}44 \\
88\end{array}$ & $\begin{array}{l}38 \\
86\end{array}$ \\
\hline $\begin{array}{l}\text { T. vaginalis foun } \\
\text { No. } \\
\text { Per cent. }\end{array}$ & $\begin{array}{l}\mathrm{d}(\mathrm{ct} \\
\cdots \\
\cdots\end{array}$ & $\begin{array}{c}\text { ulat } \\
\cdots \\
\cdots\end{array}$ & $\begin{array}{l}\cdots \\
\cdots \\
\cdots\end{array}$ & $\begin{array}{l}\cdots \\
\cdots \\
\end{array}$ & & & $\begin{array}{l}1 \\
1.5\end{array}$ & $\begin{array}{l}3 \\
5 \\
\end{array}$ & $\begin{array}{l}4 \\
7 \\
\end{array}$ & $\begin{array}{r}6 \\
12 \\
\end{array}$ & $\begin{array}{r}6 \\
14 \\
\end{array}$ \\
\hline Late default & . & . & . & $\cdots$ & & 2 & 5 & 11 & 16 & 21 & 27 \\
\hline Immediate defau & & $\cdots$ & . & $\cdots$ & 18 & 18 & 18 & 18 & 18 & 18 & 18 \\
\hline Total . . & $\cdots$ & $\cdots$ & $\cdots$ & $\cdots$ & 89 & 89 & 89 & 89 & 89 & 89 & 89 \\
\hline
\end{tabular}

* From start of treatment.

proved satisfactory for ten weeks, when he was once again found to have symptomless trichomonal urethritis. He then admitted that he was married and had never had extramarital intercourse. He was given a further course of metronidazole, and brought his wife for examination. She was found to have trichomonal vaginitis and was given sufficient metronidazole for a course of treatment lasting seven days. She defaulted immediately. Eleven weeks later the husband re-attended because of trichomonal urethritis and the wife re-attended with trichomonal vaginitis. They were treated simultaneously with metronidazole and then completed observation with negative tests for three months. The wife admitted that she had only taken one tablet of those prescribed in her original course of treatment; the remainder had been consumed by her husband when he had developed a recurrence of urethral discharge after marital intercourse.

TABLE XVII

ASSESSMENT OF RESULTS

(EXCLUDING PROBABLE RE-INFESTATIONS)

\begin{tabular}{|c|c|c|c|c|c|}
\hline \multirow{2}{*}{ Time } & \multirow{2}{*}{$\begin{array}{l}\text { No. of } \\
\text { Cases }\end{array}$} & \multicolumn{2}{|c|}{ Success } & \multicolumn{2}{|c|}{ Failure } \\
\hline & & No. & Percent. & No. & Percent. \\
\hline $\begin{array}{l}\text { Immediate } \\
\text { At } 3 \text { months }\end{array}$ & $\begin{array}{l}71 \\
41\end{array}$ & $\begin{array}{l}71 \\
38\end{array}$ & $\begin{array}{r}100 \\
93\end{array}$ & $\overline{3}$ & $\overline{7}$ \\
\hline
\end{tabular}

If the recurrent attacks in this case are accepted as re-infestations, the results of treatment were as shown in Table XVII.

The immediate success rate was 100 per cent. in 71 cases. After observation for 90 days cure was established in 38 of 41 cases (93 per cent.) and retreatment had been required in the cases of only 3 patients (excluding the patient whose history is given above).

\section{Summary}

Trichomonas vaginalis was found in 92 (5.6 per cent.) of 1,646 cases of non-gonococcal urethritis in males diagnosed at the Whitechapel Clinic of The London Hospital in the year beginning July 1, 1960.
This group of patients was studied, and the manifestations of trichomoniasis and associated findings are recorded.

Treatment with $200 \mathrm{mg}$. metronidazole by mouth 3 times a day for 7 days gave an immediate success rate of 100 per cent. in 71 cases, and a success rate after 90 days of 93 per cent., excluding probable re-infestations, in 41 cases followed for that period of time.

We are grateful to Messrs May \& Baker Ltd. for supplies of metronidazole ("Flagyl").

\section{REFERENCE}

Oates, J. K. (1958). Brit. J. vener. Dis., 34, 250.

Infestation par le trichomonas Étude de la maladie et de son traitement

RÉSUMÉ

\section{Chez la femme}

On trouva 513 cas d'infestation par le trichomonas vaginalis (chez 449 malades) parmi 1.355 cas d'infection transmise par contact sexuel chez les femmes se faisant soigner au dispensaire de Whitechapel, London Hospital, pendant l'année commençant le 1er juillet 1960: soit une proportion de $38 \%$. On décrit les malades et les manifestations cliniques. Un traitement de $200 \mathrm{mg}$. de metronidazole par la bouche, 3 fois par jour, pendant 7 jours, donna un taux de succés de $98 \%$ dans 284 cas et de $72 \%$ apres 3 mois dans 144 cas.

\section{Chez l'homme}

On trouva le trichomonas vaginalis dans $92(5,6 \%)$ des 1.646 cas d'urètrites non gonococciques diagnostiquées au dispensaire de Whitechapel, pendant l'année commençant le 1er juillet 1960. On étudie ce groupe de malades et on rapporte les manifestations de l'infestation à trichomonas et les symptomes associés.

Le traitement par $200 \mathrm{mg}$. de metronidazole par la bouche, 3 fois par jour, pendant 7 jours, donne un pourcentage de succès immédiat de 100 dans 71 cas et de 93 après 90 jours (en éliminant les reinfestations probables) dans 41 cas suivis pendant cette periode. 